\title{
PANDUAN AMAN “NEW NORMAL” MENGHADAPI PANDEMI COVID-19
}

"NEW NORMAL" SAFETY GUIDE FOR COVID-19 PANDEMIC

\author{
M. Nilzam Aly', Aprilia Nur'aini Rizma Putri², Ghina Rosyida², Aufa Hamidah*2, \\ Annisa Septiana Ahmad ${ }^{2}$, Hikmah Ayu Suryani ${ }^{2}$, Afil Qurrota A'yuni ${ }^{2}$, Putri \\ Hamidah Khairunnisa $^{2}$, Nisrina Nadia Rachmadicha ${ }^{2}$, Isrini Qaidatul Ilmi ${ }^{2}$ \\ ${ }^{1}$ Fakultas Vokasi, ${ }^{2}$ Pendidikan Apoteker, Fakultas Farmasi, Universitas Airlangga \\ email: aufa.hamidah-2017@ff.unair.ac.id
}

\begin{abstract}
In the midst of ongoing pandemic and the start of New Normal, the community is required to comply with health protocols when doing their daily activities. This will changes almost all aspects and order in society so that adaptation is needed. Many people feel burdened because it will limit themselves to show off, to develop skills, and even limiting their income. Therefore, they refuse to follow protocols and assume New Normal means returning back to normal. Community perspective on the understanding of New Normal and how to adapt which is sometimes not appropriate will make it difficult to prevent the spread of COVID-19. Therefore, we held a Community Service Program in the form of WEBINAR, online seminar education which is practical and doesn't need to gather people crowds. This WEBINAR aims to revise people's perspectives on New Normal and to give the correct adaptation methods. Moreover, this WEBINAR is also about ways to develop themselves and create innovations during this pandemic, given there are social, communication, and transportation restriction. The WEBINAR was held online using the Zoom meeting platform and was held on June $18^{\text {th }} 2020$ at 19.00 WIB with the speaker namely Ms. Ayu Tarantika Indreswari, S.Farm., Apt. The WEBINAR was attended by more than 100 participants from various cities and was dominated by teenagers. The goals of the following WEBINAR is increase the understanding and awareness of the community in implementing New Normal without limiting it to still look beautiful, stay healthy, and still earn a living. Of course, the correct adaptation of New Normal will help prevent the spread of COVID-19.
\end{abstract}

Keywords: New normal, COVID-19, health protocol.

\begin{abstract}
abstrak
Di tengah masa pandemi yang masih berlangsung dan dimulainya New Normal, masyarakat dituntut untuk tetap mematuhi protokol kesehatan dalam beraktivitas sehari-hari. Hal ini mengubah hampir sebagian aspek dan tatanan dalam masyarakat sehingga adaptasi sangat diperlukan. Banyak dari masyarakat yang merasa terbebani akan hal itu karena akan membatasi mereka dalam menampilkan diri, mengembangkan bakat, dan bahkan membatasi penghasilan mereka. Sehingga dengan berbagai alasan tersebut mereka menolak mengikuti protokol New Normal dan menganggap New Normal berarti kembali seperti normal. Perspektif masyarakat mengenai pengertian New Normal dan cara menerapkannya yang terkadang belum tepat akan menyulitkan upaya pencegahan penyebaran kasus COVID-19. Oleh karena itu, kami mengadakan program KKN berupa WEBINAR, seminar edukasi daring yang praktis tanpa harus mengumpulkan kerumunan orang di lapangan. WEBINAR ini bertujuan untuk meluruskan perspektif masyarakat mengenai New normal dan cara adaptasi yang benar. Selain itu, WEBINAR ini juga mengenai cara untuk mengembangkan diri dan menciptakan inovasi di masa pandemi, menghingat terdapat pembatasan sosial, komunikasi, dan transportasi. WEBINAR diadakan secara daring dengan menggunakan platform meeting Zoom dan dilaksanakan pda tanggal 18 Juni 2020 pukul 19.00 WIB dengan pemateri yaitu Kak Ayu Tarantika Indreswari., S.Farm., Apt. WEBINAR diikuti 118 peserta dari berbagai kota, dan didominasi oleh remaja. Diharapkan dengan adanya WEBINAR berikut, akan meningkatkan
\end{abstract}


pemahaman dan kesadaran masyarakat dalam menerapkan New Normal tanpa membatasi untuk tetap tampil cantik, tetap sehat, dan tetap berinovasi. Tentunya, penerapan New Normal yang benar akan membantu mencegah penyebaran COVID-19.

Kata kunci: New normal, COVID-19, protokol kesehatan

\section{PENDAHULUAN}

Pada Desember 2019, kasus pneumonia misterius pertama kali dilaporkan di Wuhan, Provinsi Hubei. Sumber penularan kasus ini masih belum diketahui pasti, tetapi kasus pertama dikaitkan dengan pasar ikan di Wuhan. ${ }^{[1]}$ Tanggal 18 Desember hingga 29 Desember 2019, terdapat lima pasien yang dirawat dengan Acute Respiratory Distress Syndrome (ARDS). ${ }^{[2]}$ Sejak 31 Desember 2019 hingga 3 Januari 2020 kasus ini meningkat pesat, ditandai dengan dilaporkannya sebanyak 44 kasus. Tidak sampai satu bulan, penyakit ini telah menyebar di berbagai provinsi lain di China, Thailand, Jepang, dan Korea Selatan ${ }^{[3]}$. Virus ini dapat ditularkan dari manusia ke manusia dan telah menyebar secara luas di China dan lebih dari 190 negara dan teritori lainnya. ${ }^{[4]}$ Pada 12 Maret 2020, WHO mengumumkan COVID-19 sebagai pandemik. ${ }^{[5]}$ Hingga tanggal 29 Maret 2020, terdapat 634.835 kasus dan 33.106 jumlah kematian di seluruh dunia.

COVID-19 pertama dilaporkan di Indonesia pada tanggal 2 Maret 2020 sejumlah dua kasus $^{[6]}$. Data 31 Maret 2020 menunjukkan kasus yang terkonfirmasi berjumlah 1.528 kasus dan 136 kasus kematian ${ }^{[7]}$. Tingkat mortalitas COVID-19 di Indonesia sebesar $8,9 \%$, angka ini merupakan yang tertinggi di Asia Tenggara. Hingga saat ini jumlah kasus positif masih terus meningkat, diikuti dengan angka kematian yang juga meningkat. Hingga saat ini (25 Juli 2020) di Indonesia sudah mencapai angka 95.418 kasus positif, dan 4.665 kasus kematian. Provinsi Jawa Timur menduduki posisi pertama dengan jumlah kasus positif terbanyak, yakni berjumlah total 19.946 kasus positif. Di daerah Sidoarjo sendiri saat ini sudah tercatat sebanyak 2.911 kasus positif yang menjadikan wilayah Sidoarjo merupakan zona merah. Persebaran kasus positif COVID-19 di wilayah Sidoarjo dapat dilihat pada gambar berikut ini.

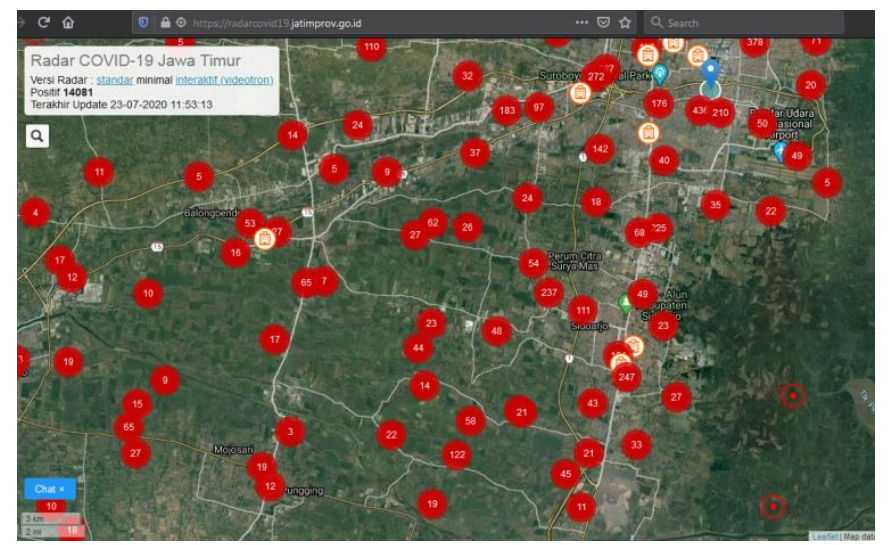

\section{Gambar 1. Peta Persebaran Kasus COVID-19 di Sidoarjo}

Sumber : https://radarCOVID19.jatimprov.go.id/

Dari data persebaran tersebut dapat disimpulkan bahwa sangat tidak memungkinkan untuk melakukan suatu kegiatan dengan mengumpulkan banyak orang, sedangkan masyarakat juga memerlukan banyak informasi terkait cara melakukan pencegahan dan menjaga daya tahan tubuh. Istilah New Normal disalahartikan oleh beberapa masyarakat 
berupa "Normal yang Baru"atau kembali beraktivitas seperti semula, padahal yang dimaksud New Normal adalah adaptasi kebiasaan baru, artinya beraktivitas dengan menerapkan protocol kesehatan (memakai masker, menerapkan pola hidup bersih dan sehat, dan lain-lain). Diberlakukannya adaptasi kebiasaan baru namun peningkatan kasus positif tetap tinggi, bahkan lebih besar dari sebelumnya membuktikan bahwa masih banyak orang yang tidak mematuhi protocol kesehatan. Hal inilah yang mendasari kami untuk menemukan cara agar dapat memberi edukasi kepada masyarakat namun tidak dengan cara mengumpulkan banyak orang.

Cara yang kami pilih untuk memberi edukasi pada masyarakat adalah melalui WEBINAR, yakni seminar yang dilakukan secara online dengan materi yang dibawakan sesuai dengan kondisi dan kebutuhan informasi masyarakat saat ini, yakni New Normal.WEBINAR atau seminar online merupakan wadah yang berisi pembelajaran, workshop, pembahasan permasalahan, informasi, diskusi, dan lain lain yang dibina oleh narasumber atau pakar di bidangnya secara daring. WEBINAR sendiri diadakan melalui media Zoom, Cisco Webex, Google Meeting, Live Streaming, dan lain sebagainya.

Di masa pandemi COVID 19, WEBINAR banyak digunakan karna berbagai peserta yang tersebar dari berbagai penjuru dunia dapat berkumpul dan berdiskusi tanpa berinteraksi dan bertatap muka secara langsung sehingga mengurangi dari kemungkinan terpapar virus corona. WEBINAR pun praktis karna bisa diakses melalui barang elektronik seperti handphone, laptop, dan komputer tanpa harus pergi ke tempat dilaksanakannya seminar.Seminar online dapat dilihat sebagai sistem baru, komunikatif dan teknis konteks untuk melanjutkan dalam perumusan dan penelitian secara pengetahuan kritis. Sistem ini memperkenalkan cara berkomunikasi, dan menawarkan beberapa fitur positif serta beberapa potensi yang penting untuk dipelajari. Yang perlu diperhatikan dalam seminar online adalah ide tema, perkembangan saat seminar berlangsung beserta kondisi spesifik peserta dimana hasil dari kegiatan ini adalah nilai untuk peserta. Masalah krusial di sini adalah bagaimana para peserta dapat memahami masalah yang dibahas, dan bagaimana wawasan mereka berkembang selama mereka mengikutinya. Sesuai dengan webinar/seminar online yang kami adakan dengan tema "New normal? Be healthy, Be beauty, Be wealthy" dengan beberapa permasalahan di dalamnya seperti kesehatan, kecantikan, maupun keuangan. Para peserta juga terus dipantau dengan adanya nilai untuk mengetahui perkembangan wawasan mereka sebelum dan sedah seminar online berlangsung.

Pada saat COVID-19, peran WEBINAR penting untuk mengedukasi dan menginformasikan kepada masyarakat. Tujuan kami menyelenggarakan WEBINAR adalah kami ingin berbagi ilmu dengan orang lain karena hal ini penting untuk disampaikan ke masyarakat. WEBINAR ini tidak hanya mengenai pencegahan agar terhindar dari COVID-19, tetapi juga cara untuk mengembangkan diri dan menciptakan inovasi di masa pandemic ini, mengingat masyarakat dianjurkan untuk tetap berada di rumah. Dengan dilaksanakannya WEBINAR ini, masyarakat dapat menambah dan memperluas wawasannya mengenai COVID-19, dapat mengeksplorasi hal-hal yang baru dan mengembangkan skill baru dengan cara melakukan improvisasi dan inovasi terhadap sesuatu. Manfaat dari mengikuti WEBINAR adalah kita dapat mengisi waktu luang dengan menambah ilmu, berdiskusi atau berbincang bincang dengan menambah relasi sehingga dapat mengusir rasa bosan karna harus mengikuti kebijakan pemerintah untuk stay at home dan social distancing. 
Pada program kerja kami, kami memutuskan untuk menyediakan WEBINAR secara gratis karena dapat mempermudah mendapatkan peserta, selain itu kami juga menyediakan E-sertifikat dan pemateri yang menarik sehingga dapat menarik minat peserta. Sasaran kami adalah masyarakat berusia 15-25 tahun dari berbagai daerah dan kegiatan ini dilakukan melalui Zoom.

\section{METODE PENGABDIAN MASYARAKAT}

Berdasarkan pemaparan tersebut, kami menyadari perlunya dilakukan suatu upaya untuk menambah wawasan masyarakat akan pentingnya kesadaran diri mematuhi protokol kesehatan selama pandemi dengan penerapan New Normal. Menargetkan masyarakat umum yang berada pada rentang usia 15-25 tahun, dengan fokus bahasan yaitu mengenai kesehatan dan perekonomian.

WEBINAR bertema 'Be Healthy, Be Beauty, Be Wealthy' diselenggarakan melalui media Zoom dengan total 156 pendaftar dan 117 peserta yang dibuktikan dengan pengisian pre-test dan post-test sebagai absensi juga evaluasi kegiatan. Pre-test dan post-test berisi 10 soal pilihan ganda seputar materi/pembahasan yang disampaikan oleh pembicara, bertjuan mengetahui tingkat pemahaman peserta WEBINAR baik sebelum maupun sesudah diselenggarakannya acara.

\section{HASIL DAN PEMBAHASAN}

WEBINAR "New Normal? be Healthy, be Beauty, be Wealthy" bertujuan untuk menambah wawasan peserta mengenai cara agar badan tetap sehat, tubuh tetap terawat, dan pemasukan tetap berlipat pada era new normal ini. Untuk mencapai tujuan, tolak ukur yang menjadi patokan adalah meningkatnya nilai peserta dari pre-test (sebelum WEBINAR) ke post-test (setelah WEBINAR). Persentase benar dan salah pada jawaban peserta di setiap soal (Tabel 1) menunjukkan peningkatan dari pre-test ke post-test, sehingga pada ringkasan nilai dari pre-test ke post-test (Tabel 2) menjadi meningkat. Indikator keberhasilan yang lain adalah jumlah peserta yang mendaftar, dengan total 165 pendaftar dari yang ditargetkan 20 peserta.

Tabel 1. Perhitungan Persentase Benar Salah pada Setiap Poin Pertanyaan

\begin{tabular}{|c|c|c|c|c|c|}
\hline \multirow{3}{*}{$\begin{array}{l}\text { Nomor } \\
\text { Soal }\end{array}$} & \multirow{3}{*}{ Indikator Pertanyaan } & \multicolumn{4}{|c|}{ \% Responden } \\
\hline & & \multicolumn{2}{|c|}{ Pre-test } & \multicolumn{2}{|c|}{ Post-test } \\
\hline & & Benar & Salah & Benar & Salah \\
\hline 1. & Metode pemeriksaan untuk COVID-19 & $85,7 \%$ & $14,3 \%$ & $94,9 \%$ & $5,1 \%$ \\
\hline 2. & $\begin{array}{l}\text { Langkah pencegahan penyebaran COVID- } \\
\qquad 19\end{array}$ & $83 \%$ & $17 \%$ & $94,9 \%$ & $5,1 \%$ \\
\hline 3. & $\begin{array}{c}\text { Suplemen/vitamin untuk individu sehat } \\
\text { negatif COVID-19 }\end{array}$ & $91,2 \%$ & $8,8 \%$ & $94,1 \%$ & $5,9 \%$ \\
\hline 4. & Karakteristik virus COVID-19 & $76,2 \%$ & $23,8 \%$ & $90,7 \%$ & $9,3 \%$ \\
\hline 5. & $\begin{array}{l}\text { Sejarah penyakit COVID-19 muncul } \\
\text { pertamakali }\end{array}$ & $99,3 \%$ & $0,7 \%$ & $99,2 \%$ & $0,8 \%$ \\
\hline 6. & $\begin{array}{c}\text { Cara untuk menjaga daya tahan tubuh } \\
\text { dengan baik }\end{array}$ & $67,1 \%$ & $32,9 \%$ & $83,9 \%$ & $16,1 \%$ \\
\hline 7. & Gejala ringan COVID-19 & $87,8 \%$ & $12,2 \%$ & $96,6 \%$ & $3,4 \%$ \\
\hline
\end{tabular}


8.

9.

10.
Pengetahuan tentang new normal

Bahan herbal dapat membantu menjaga daya tahan tubuh

Cara menjaga mental health yang kurang baik

$\begin{array}{cccc}98,6 \% & 1,4 \% & 99,2 \% & 0,8 \% \\ 98,6 \% & 1,4 \% & 100 \% & 0 \% \\ 42,9 \% & 57,1 \% & 60,1 \% & 39,9 \%\end{array}$

Tabel 2. Ringkasan Nilai

\begin{tabular}{cccccc}
\hline & Pre-test & & & Post-test & \\
\hline Rata-rata & Median & Rentang & Rata-rata & Median & Rentang \\
\hline $79,25 / 100$ poin & $80 / 100$ poin & $20-100$ poin & $88,98 / 100$ poin & $90 / 100$ poin & $60-100$ poin \\
\hline
\end{tabular}

Dalam pelaksanaan WEBINAR ini, terdapat beberapa kelebihan dan kekurangan. Beberapa kelebihan seperti 1) Pelaksanaan secara online sehingga menghemat biaya untuk konsumsi, 2) Dapat diikuti oleh seluruh masyarakat dengan rentang usia 15-25 tahun dari seluruh daerah dan instansi dengan mudah, 3) Pendaftaran gratis, 4) Peserta berhak mendapatkan e-sertifikat. Namun disamping beberapa kelebihan tersebut, WEBINAR ini juga memiliki beberapa kekurangan seperti 1) Kurangnya interaksi penyelenggara dengan peserta, maupun sesama peserta karena hanya admin (penyelenggara) yang bisa mengirim pesan di grup whatsapp, 2) Kurangnya interaksi antara peserta dengan pembicara karena video dan audio peserta hanya dinyalakan saat ingin bertanya ataupun foto bersama, 3) Peserta dibatasi untuk bertanya, karena hanya 4 orang saja yang mau bertanya dengan menyalakan audio video sehingga hanya 4 orang tersebut yang mendapatkan doorprize pulsa.

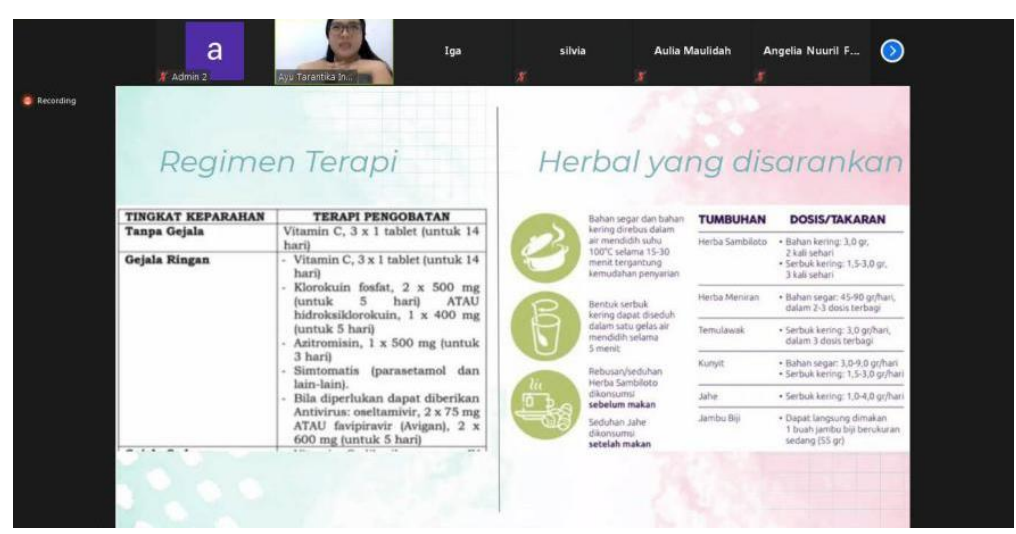

Gambar 1. Pelaksanaan WEBINAR "New Normal? be Healthy, be Beauty, be Wealthy" 


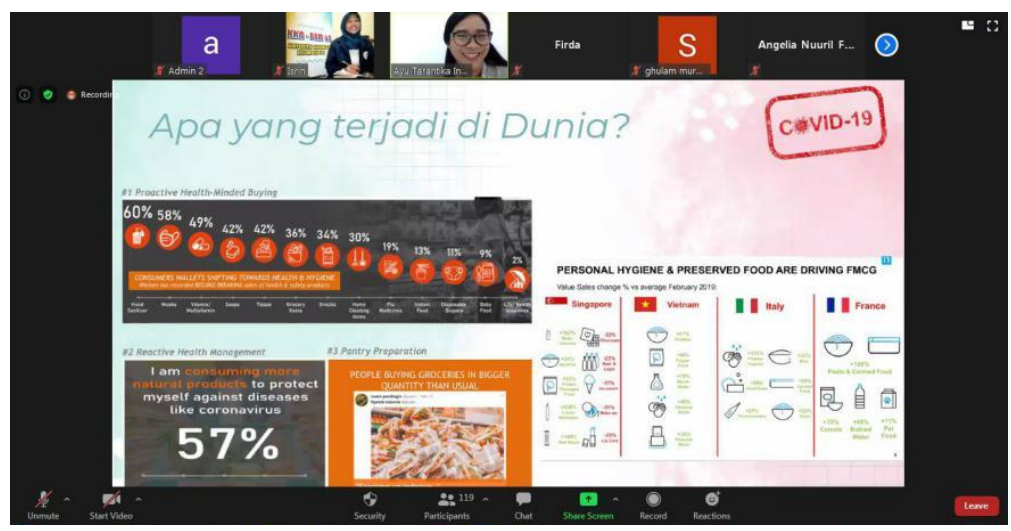

Gambar 2. Pelaksanaan WEBINAR "New Normal? be Healthy, be Beauty, be Wealthy"

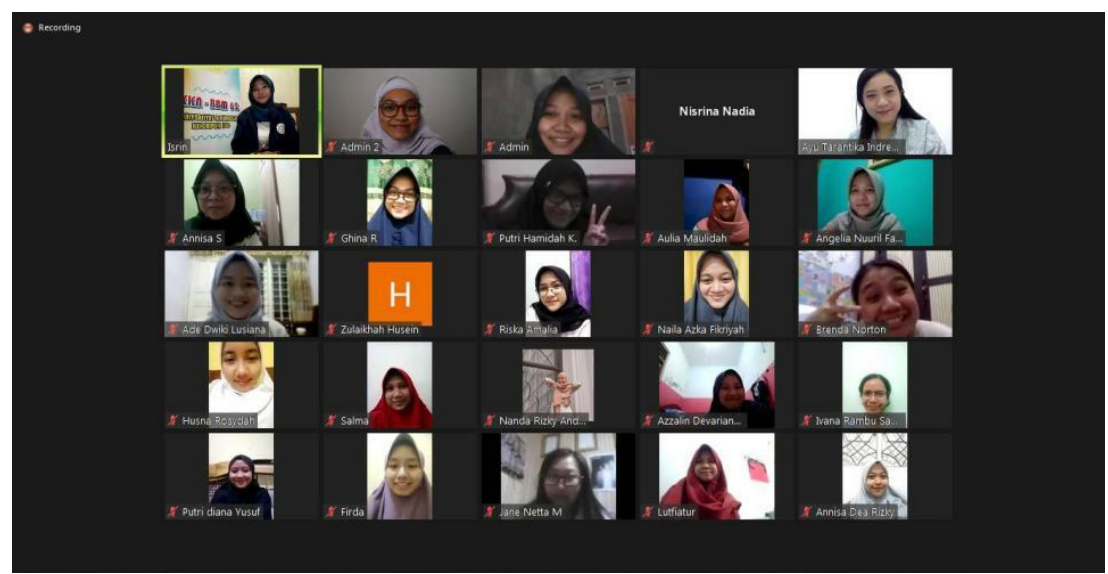

Gambar 3. Pelaksanaan WEBINAR "New Normal? be Healthy, be Beauty, be Wealthy"

Grafik 1. Persebaran Domisili Peserta

\section{Persebaran Domisili Peserta}

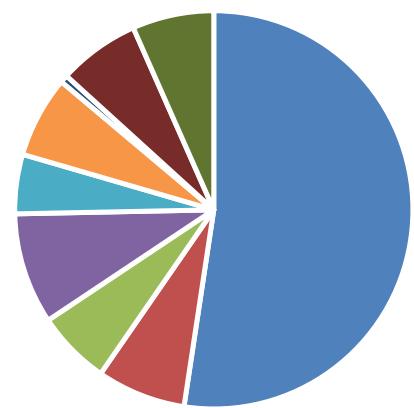

$$
\begin{aligned}
& \text { - Jawa Timur - Jawa Tengah - Jawa Barat - JABODETABEK }- \text { Kalimantan } \\
& \text { - Sumatera } \quad \text { - Bapua } \quad \text { Dali.Y }
\end{aligned}
$$




\section{PENUTUP}

\section{Kesimpulan}

1. Peserta dapat dengan mudah menerima dan memahami materi yang telah dijelaskan oleh pembicara.

2. Terjadi peningkatan pengetahuan mengenai informasi untuk melakukan protokol new normal. Hal tersebut dapat dilihat dari hasil pretest ke postest.

3. Program WEBINAR dinyatakan berhasil mencapai tujuan dan target yang diinginkan. terjadinya peningkatan nilai dr pre ke postes, dan jumlah peserta mencapai 160 peserta merupakan tolak ukur keberhasilan program ini.

\section{Saran}

1. WEBINAR dapat berlanjut dengan materi yang berbeda selama era new normal yang tidak memperbolehkan berkumpul dengan jumlah orang yg banyak.

2. Diperlukan persiapan materi yang baik agar kegiatan dapat berjalan lancar dan mencapai tujuan.

\section{UCAPAN TERIMA KASIH}

Penulis mengucapkan terima kasih kepada pihak Lembaga Pengabdian dan Pengembangan Masyarakat (LPPM) Universitas Airlangga atas dukungan finansial untuk pelaksanaan pengabdian masyarakat dan pihak-pihak lain yang terlibat di dalamnya.

\section{DAFTAR PUSTAKA}

Andriani, H. (2020). Effectiveness of Large-Scale Social Restrictions ( PSBB ) toward the New Normal Era during COVID-19 Outbreak: a Mini Policy Review. $5(2), 61-65$.

Dinas Kesehatan Provinsi Jawa Timur. 2020. Radar COVID-19 Jawa Timur. https://radarCOVID19.jatimprov.go.id/ (Diakses pada 24 Juli 2020)

Huang C, Wang Y, Li X, Ren L, Zhao J, Hu Y, et al. Clinical features of patients infected with 2019 novel coronavirus in Wuhan, China. Lancet. 2020;395(10223):497-506.

Kementerian Kesehatan Republik Indonesia. Info Infeksi Emerging Kementerian Kesehatan RI [Internet]. 2020 [updated 2020 March 30; cited 2020 March 31]. Available from: https://infeksiemerging.kemkes.go.id/.

Lars, Erik Jonsson. Roger, Saljo. 2010. The Online Seminar as Enacted Practice. IGI Global. Chapter III, 38-39. 
Rothan HA, Byrareddy SN. The epidemiology and pathogenesis of coronavirus disease (COVID-19) outbreak. J Autoimmun. 2020; published online March 3. DOI: $10.1016 /$ j.jaut.2020.102433.

Ren L-L, Wang Y-M, Wu Z-Q, Xiang Z-C, Guo L, Xu T, et al. Identification of a novel coronavirus causing severe pneumonia in human: a descriptive study. Chin Med J. 2020; published online February 11. DOI: 10.1097/CM9.0000000000000722.

World Health Organization. Coronavirus disease 2019 (COVID-19) SituationReport 70 [Internet]. WHO; 2020 [updated 2020 March 30; cited 2020 March31].Available from: https://www.who.int/docs/defaultsource/coronaviruse/situation-reports/20200330-sitrep-70-COVID19.pdf?sfvrsn=7e0fe3f8_2

World Health Organization. WHO Director-General's opening remarks at the media briefing on COVID-19 - 11 March 2020 [Internet]. 2020 [updated 2020 March 11]. Available from: https://www.who.int/dg/speeches/detail/whodirector-general-s-opening-remarks-at-the-media-briefing-on-COVID-19---11march-2020.

World Health Organization. Situation Report - 42 [Internet]. 2020 [updated 2020 March 02; cited 2020 March 15]. Available from: https://www.who.int/docs/default-source/coronaviruse/situationreports/20200302-sitrep-42-COVID-19.pdf?sfvrsn=224c1add_2. 